\title{
Introduction: \\ The Politics of Knowledge and History
}

\author{
Corey Dolgon ${ }^{1}$
}

\begin{abstract}
[Article copies available for a fee from The Transformative Studies Institute. E-mail address: journal@transformativestudies.org Website: http://www.transformativestudies.org (C2012 by The Transformative Studies Institute. All rights reserved.]
\end{abstract}

Moments of clarity in American politics are rare. The current season of Republican debates and primaries offers few exceptions. While the gaffs and hijinks provided by Newt, Mitt, Rick and Ron are already legion, the humor that paves the GOP campaign trail obfuscates more often than it illuminates. When Romney does his best Thurston Howell III impression, highlighting how different the daily lives of the very rich are from the rest of us, it shows more about his idiosyncratic aristocratic aloofness than it demonstrates how structural inequality shapes the way in which wealth and money dominate democratic processes and economic policies. And regardless of the way in which liberal pundits lament Clinton era policies or the 1960's War on Poverty, or even FDR's Economic Bill of Rights (now that was Socialism), it is important to remember that elite power and wealth have ALWAYS dominated electoral politics and economic and social policies in the United States. Inequality, discrimination, and fascism are not simply manifestations of Regan or either Bush, but have existed throughout Democratic and Republican regimes alike.

More interesting to me though, are the pearls dropped from the constipated lips of Rick Santorum. Recently, he attempted to paint Obama as an elitist because the President advocates policy initiatives to fund higher education for all. Santorum suggested that such a focus made Obama "a snob":

There are a lot of people in this country that have no desire or no aspiration to go to college, because they have a different set of skills and desires and dreams that don't include college....And to sort of lay out there that somehow this is should be everybody's goal, I

\footnotetext{
${ }^{1}$ Dr. Corey Dolgon, Associate Editor.
} 


\section{Corey Dolgon}

think, devalues the tremendous work that people who, frankly, don't go to college and don't want to go to college because they have a lot of other talents and skills that, frankly, college, you know, four-year colleges may not be able to assist them.

The Left and liberal media-Huffington Post, MSNBC, etc.- have rightfully skewered Santorum for his hypocrisy (after all he has an B.A. from Penn State, an MBA from University of Pittsburgh, and a law degree from Dickinson School of Law, his wife has dual college degrees, and his daughter attends a major college). Their primary critique is that Santorum is pandering to a working class, anti-intellectual, hard-core right-wing base. But I think this rhetoric reflects more heinous dynamics at work, ones that betray the REAL conservative agenda and how the rich and powerful maintain and manage a hegemonic bloc.

On the one hand, instead of pandering to a stereotyped, redneck, blue collar conservative working class, I suggest Santorum's claims pander more to the elite conservative corps responsible for funding Tea Party organizing, Gingrich and Romney PACs, etc. Santorum's rhetoric reassures this group that inequality and hyper social stratification is not only a moral good, but one welcomed by the poor and working class themselves. The Wall Street, Washington, and wealthy cowboy republicans can rest easy in knowing that the non-rich, white conservative base will satisfy themselves with religion, guns, racial supremacy, family values and a variety of myths about traditional ways of life. I hesitate to sound the vulgar Marxist, musing about the masses opiates. And I don't actually believe such strategies work effectively for very long. But I do think the conservative elite need to keep repackaging their grand narrative in order to rationalize, reaffirm and redeem their ascendency.

On the other hand, though, I do think there is a discursive battle being waged. The non-rich conservative base DOES need to be held in check and the "dumbing down" of huge swaths of the American population has been a vital strategy in recent class struggles. The Romney, Gingrich, Santorum, Paul cohort have a vested interest in making sure that populist discourse is extremely conservative and obfuscating, that poor and working class people continue to vote AGAINST their own interests, and that critique remain befuddled by not only the question of "What's the matter with Kansas?", but the resonant questions of "What's the matter with Nebraska, Oklahoma, Georgia, Louisiana, Wyoming?" and if they are lucky, "What's the matter with Ohio and Florida?" 
Santorum isn't so much pandering to the non-elite conservative base, as he is trying to recommit them to a self-defeating ideology. This helps to explain another of his recent pledges, "never to mention the name of previous presidents if he is elected." To effectively promote and strategically reinforce false consciousness (oops, there I go again with the vulgar Marxism), one has to be anti-historical as well as antiintellectual. To PROMISE to forget the past is an odd campaign pledge, but it goes beyond simply asserting that he will never blame problems on previous administrations. Santorum would like to promote a blank slate where the hegemonic gains of progressive and radical movements (labor rights, civil rights, environmental legislation, etc.) never happened. Santorum's entire candidacy celebrates the triumph of a radically conservative ideological campaign over the past three decades. And his continued success among party faithful suggests that, while theories of false consciousness have rightfully and effectively been critiqued for their lack of nuance and sophistication; for their seeming ignorance of the lived social history and cultural realities of everyday life; and for the agency with which non-elites actively embrace the language of the powerful; promoting false consciousness is still an active and effective strategy and must be challenged at every turn.

Armed with this analysis and commitment, we bring you some outstanding and important articles that promote and support a radical counter hegemonic project. Jesse Daniels piece on critical media literacy argues that we can have a transformative impact on our students by using documentaries in a critical context. His research suggests that critical pedagogy can produce media literacy in ways that bridge the gap between traditional content and teaching and new media opportunities.

In a similar vein, Susan Kahlberg discusses a course in health communication where attempts to use active learning infused theoretical lessons on how health issues are discussed and communicated with engaged projects about how to design public health information campaigns. Kahlberg's course and article address the particulars of how public intellectuals, armed with progressive pedagogies, can teach students not only how to critique the ideological constraints of mainstream public health messaging, but also empower them with new strategies and experiences.

Another critical pedagogy entry, Ray Muller's article "From Apathy to Activism" implores us that we can fuse e lessons about C.Wright Mills' "sociological imagination," with practical examples of civic engagement addressing the very social problems under scrutiny. In promoting a "humanist sociology," Muller suggests that a humanist pedagogy 


\section{Corey Dolgon}

provides a powerful tool for moving students from the apathy of Mills' "trap," to being actively engaged in challenging the world's problems and their root causes, thus transcending simply the analytical "quality of mind" that Mills proposed, to an "activist sociological citizenship" that Muller sees as an ultimate goal.

Daniel Rubin reinforces the analysis that neoliberal and conservative solutions to the root causes of social problems often suffer from the same ideological limitations that promise to fail. While No Child Left Behind in general and hi-stakes testing in particular continues to get support from liberals and conservatives alike, Rubin argues " there has been a move away from critical thinking and the fight for social justice" in education. He offers both a critical, dialectical critique of mainstream educational policies and presents "examples of techniques and projects which help students view the world around them in a more critical fashion."

Walsh and Tsilimpounidi focus on non-educational interventions, presenting us with the analysis of a recent hunger strike in Athens, Greece. They explain that, "the strike offered supporters the opportunity to engage more widely with debates on immigration and human rights across Europe, alongside reading the virulent effects of the economic crisis in financial capital terms and resulting neo-liberal backlashes." The strike itself became a 'performance of resistance' which not only offered a public critique of neo-liberal policies, but also created a new consciousness among those demonstrators and supporters.

Finally, Augustin Rodriguez presents a theoretical investigation of poverty, explaining "how the roots of poverty are rooted in the marginalization of the rationalities of the so called poor, a marginalization that renders them disempowered from realizing their conception of the good life." Returning to my initial thoughts on false consciousness, Rodriguez argues that "the genuine liberation of the poor demands their empowerment founded in the liberation of their rationalities [and] reformers must focus on building systems of discourse that allow the marginalized to participate in the shaping of the dominant rationalities that govern us all." A call to action, indeed! 